\title{
Analysis on the Import Strategy of the Whole Vehicle in Fuzhou Port of Fujian Free Trade Area*
}

\author{
Dan Liu \\ Department of Logistics Management \\ Fuzhou University of International Studies and Trade \\ Fuzhou, China
}

\author{
Xiulian $\mathrm{Hu}$ \\ Department of Logistics Management \\ Fuzhou University of International Studies and Trade \\ Fujian, China
}

\author{
Chong Ye \\ School of Economic and Management \\ Fuzhou University \\ Fujian, China
}

\begin{abstract}
With the establishment of Fujian Free Trade Area and the advantage of its development policy, the development of whole vehicle imports is facing unprecedented development opportunities. In this paper, Grey prediction is applied to predict the import volume of foreign trade whole vehicle in Fuzhou port in the next five years, and the fitting degree test and error verification are carried out. Based on the prediction results, combined with the actual capacity of Fuzhou port, we discuss the development of Fuzhou port's whole vehicle import under the background of the free trade area. Finally, the paper targetedly puts forward some suggestions such as giving full play to the advantages of policy support and strengthening the construction of supporting facilities so as to promote the development of the whole vehicle import of Fuzhou Port and realize the large-scale and systematic development of Fuzhou Port as soon as possible.
\end{abstract} import

Keywords-whole vehicle import; Fuzhou port; free trade area;

\section{INTRODUCTION}

With the sustained and rapid development of our country's economy, the standard of living of the people has been steadily improved, and the automobile has gradually become a particularly important part in the daily life of the common people. Therefore, for the larger part of consumers, under the same cost conditions, imported cars have always been favored by most consumers with higher quality and lower fuel consumption. Therefore, what brings along is our country imports the vehicle demand unceasingly to raise. While the people's consumption ability is improved, the tendency of many consumers to buy cars is changed from the original middle and low grade to the middle and high grade imported cars, The middle and low grade vehicles in China are difficult to meet the needs of the consumers, This also leads to the import car market and brings a large number of imported car orders. Therefore, how to complete the whole vehicle import quickly, efficiently and at low cost has also become an

*This paper is supported by the fund of "2017 Fujian Province university outstanding young scientific research talent training program". important factor in driving the import vehicle market.

According to the various ways of the import of the whole vehicle, the current international transportation related to the import and export of vehicles is focused on ship transportation as the main mode of transportation, using the ships carrying the whole vehicle, carrying the cargo from the export country to the import country of the vehicle, so as to complete a batch of whole vehicle import and export business. Therefore, the operation of the port also plays a vital role in the whole vehicle import link.

Fuzhou Port, as an important trade port in Fujian Province, was officially launched with Xiamen and Pingtan as part of Fujian Free Trade Area on April 21, 2015.As the front position of the southeast coastal port development, Fuzhou Port has attracted a lot of development opportunities by virtue of its superior geographical position and favorable policy since the establishment of the Free Trade Area. At the same time, under the favorable policy support, the cost of Fuzhou port development is greatly reduced, the highest degree of integration of high-quality resources, accelerate the port development process, and win a rare opportunity for the further development of the port.

\section{GENERAL SituAtion OF WHOLE VEHICLE IMPORT IN FUZHOU PORT}

In early January 2013, the State Joint acceptance Group, composed of the General Administration of Customs, the Ministry of Industry and Information, the Ministry of Commerce, and the State Administration of quality Supervision, carried out further acceptance of the import ports of whole vehicles in the Jiangyin Port District of Fuzhou Port, and signed the summary of the acceptance of the whole process. This symbolizes that the whole vehicle import business of Jiangyin port entered the stage of formal putting into use.

At present, Jiangyin port is still in the initial stage of development, the whole car imports are divided into two 
categories, namely domestic trade imports and foreign trade imports. The import of domestic trade refers to the way of domestic production of vehicles transported to Jiangyin port at other ports in the country. Foreign trade port refers to the way of direct shipment of foreign manufactured whole vehicles to Jiangyin port.[1]At present, the import of whole vehicles in Jiangyin port is mainly domestic trade and foreign trade is subsidiary. Jiangyin port whole vehicle is mainly imported from Taiwan line, Hongkong line and the US west line, the domestic trade whole vehicle is mainly imported from Yingkou line, and most of them are BMW Brilliance. In 2014, the whole vehicle import business of Jiangyin Port area of Fuzhou Port has developed steadily this year, with a total of 9500 vehicles imported in the whole year, an increase of $121.8 \%$ over the same period last year, among them, the import volume of foreign trade whole vehicles is 2294.According to the statistics of Fuzhou customs, the import volume of foreign trade whole vehicles at Jiangyin port of Fuzhou port ranked first in the national new vehicle opening port. As of December 15, 2017, the import volume of foreign trade vehicles in Jiangyin Port District of Fugang collection box exceeded 10, 000 vehicles for the first time this year, with a cumulative total of 10010 vehicles. Of course, such a rapid growth cannot be separated from the establishment of the free trade area for its convenience conditions support, I believe in the future development of Jiangyin port, the convenience of the free trade area will also become a strong boost to the development of port construction.

\section{PROBLEMS EXISTING IN THE IMPORT OF THE WHOLE VEHICLE IN FUZHOU PORT}

\section{A. Analysis of Non-quantitative Influencing Factors}

1) Weak Foundation of Supporting Facilities in Port Area: At present, Jiangyin Port is a good natural port with a coastline of more than 2,000 meters and a port depth advantage for the largest container ship in the world. This is indeed an essential advantage for a port area where the vehicle is imported, and it is not enough to have only a certain area of docked area and an area of land operation. With reference and understanding of the development of advanced whole vehicle import port at home and abroad, taking Shanghai Haitong international automobile terminal as an example, as the dominant port in the field of domestic whole vehicle import, the port has been particularly attached to the development of infrastructure construction in the port area on the premise of good geographical position advantages, and has completed construction of rolling wharf and the rolling line have been opened at the beginning of the construction, for the import of the whole vehicle, it is particularly important to use the rolling ship transportation, on the one hand, the import and transportation modes of all the major automobile brands both at home and abroad are transported by the rolling ship, this way of transportation can greatly improve the competitiveness of its own port and attract large quantities of domestic and foreign large auto brands to port at this port; on the other hand, as the preferred transportation mode of the rolling ship transportation as the import of the whole vehicle, all the loading and unloading ships can be completed for a short time and high quality, this also greatly saves the loading and unloading time and improves the port's throughput. However, at present, the port area of Jiangyin has not yet built a rolling Wharf, nor has it opened a rolling line[3].Not only that, compared with the same level ports, the existing warehouses in Jiangy in port are relatively low, and the warehouse types are single and the functions are not comprehensive enough. The long-built Shanghai Port has a storage area of 470,000 square meters, which can also provide parking demand for 25,000 finished vehicles, with a capacity of up to 1 million vehicles per year. As a result, the operation efficiency of vehicle entry and exit is low. Compared with other large ports, this is at a disadvantage in terms of the competitiveness of port hardware facilities. [2]

2) Low Level of Information: At present, in the field of port whole vehicle import, the advanced large ports make full use of the advantages brought by the information operation, From cargo to port until the whole process of goods being shipped out of port, the information management and recording are adopted. On the one hand, the efficiency is improved, the accuracy of the operation is enhanced, and the use of human resources is also reduced, it is a highly efficient operation mode and a necessary trend for future port development to reduce a large number of costs for enterprise operation. At present, in Jiangyin Port, facilities related to the whole vehicle import business, such as barcode EDIGPS and other information technologies, have not yet been widely used, and Jiangyin Port has not yet been involved in the field of scientific and technological development and innovation, and its technical development capability is relatively weak, to a great extent, it limits the advantage of information technology in the Development of port whole vehicle port.

3) Single service type: According to the development of Jiangyin port area at present, after the whole vehicle is imported into port, a series of work such as unpacking, customs clearance, national inspection, storage and so on will be carried out according to the relevant procedures. Subsequently, the vehicles that have already been stored will wait to pick up goods according to the needs of different cargo owners. In this way, the general vehicle import work in the port area is basically over. For the whole vehicle import field, the development of the related service business after the whole vehicle enters the port is also a good way to attract the large brand vehicles to enter the port and create the revenue. At this point, Jiangyin port has not made more attempts, the essential step of simply completing the imported vehicles is the operation standard, which also restricts the further development of the port business to a certain extent.

\section{B. Analysis of Quantitative Influence Factors}

1) Lack of ability to predict the import volume of foreign trade whole vehicle: At present, Jiangyin port is at a preliminary stage of development, from the initial annual 
import of more than 300 vehicles to the current annual import of 10, 000 vehicles, Jiangyin port has only taken four years. For several years, Jiangyin port has been increasing exponentially. However, due to promotion of policy factors in recent years, the impact of sudden cases, which resulted in large fluctuations in the annual foreign trade whole vehicle import volume of Jiangyin port, which has a certain instability, and the growth situation has also produced great uncontrollable changes in the last two years. $\circ$ As a result, for Jiangyin Port, in the short term, there is a lack of forecasting capacity for the number of foreign trade imported vehicles in the port, The current volume of foreign trade whole vehicle imports is not in accordance with the actual development, This has greatly affected the port infrastructure, import quota declaration and other aspects of the work. It is difficult to predict accurately and reasonably the passing capacity of the port for some time to come, which also hinders the development prospect of Jiangyin port in the field of whole vehicle import to some extent

\section{PREDICTION OF IMPORT VOLUME OF FUZHOU PORT'S ForEIGN TRADE WHOLE VEHICLE BASED ON GREY PREDICTION THEORY}

\section{A. Grey Prediction Theory}

Grey prediction theory refers to an operation method of data prediction and processing based on the system composed of various uncertain factors. Grey prediction theory is to identify the differences between the system factors in the future development trend, analyze the correlation degree according to its general significance, and to further process the original data to find the variation law in the system, and then generate the data sequence with strong arrangement law, then the corresponding differential equation model is established, and through the established equation model, we can predict the trend of things in the future development.[4]In this paper, the import volume of port foreign trade whole vehicle is influenced by many factors, and it is uncertain, it is suitable for Grey prediction model in theory.

This paper studies the development and analysis of the whole vehicle import situation in Fuzhou Port, at the same time, the Jiangyin Port area, the only one in Fuzhou Port that deals with the whole vehicle import business, is our main research object and data source, however, the whole vehicle import business of Jiangyin Port has only been operated for more than four years, it is still in the initial stage of the development of the port area, the relevant data are still not perfect and comprehensive, and there are certain uncertainties at the same time, so this paper chooses to use the grey forecasting system, according to the development of the port area in the past few years, forecast the development trend of the whole vehicle import in Jiangyin port area in the next few years, and take this as the reference basis and combine the existing problems, make an improvement and optimization scheme for quantifiable parts, so as to promote the good development momentum of Fuzhou Port.

\section{B. Construction and Solution of Grey Prediction Theory Model}

1) The construction of import volume of Fuzhouport's foreign trade whole vehicle forecasting model: According to the import volume of the foreign trade vehicle completed in the Jiangyin port area in 2014-2017 years, the data of each year are aggregated into cumulative generating series and into the Grey forecast GM $(1,1)$,the prediction model of import volume of Jiangyin port's foreign trade whole vehicle is formed, and the model is tested.

TABLE I. IMPORT VOLUME OF ForeIGN TRADE WHOLE VEHICLES IN JIANGYIN PORT, 2014-2017

\begin{tabular}{|c|c|c|c|c|}
\hline Year & 2014 & 2015 & 2016 & 2017 \\
\hline Annual import volume & 2294 & 3878 & 8311 & 10010 \\
\hline
\end{tabular}

sequence $\mathrm{X}^{(0)}=\left(x^{(0)}(1), x^{(0)}(2), \cdots, x^{(0)}(n)\right)$, do an accumulative generation sequence, get

$$
\begin{aligned}
& \mathrm{X}^{(1)}=\left(x^{(1)}(1), x^{(1)}(2), \cdots, x^{(1)}(n)\right) \\
& =\left(x^{(1)}(1), x^{(1)}(1)+x^{(0)}(2), \cdots, x^{(1)}(n-1)+x^{(0)}(n)\right)
\end{aligned}
$$

Among them,

$x^{[1](1)}(1)=x^{[0]}(1)$

Establish Albino differential equation:

$$
\frac{d x^{[1]}}{d t}+a x^{[1]}=b
$$

Set $u=[a, b]^{\mathrm{T}}=\left(\mathrm{B}^{\mathrm{T}} \mathrm{B}\right)^{-1} \mathrm{~B}^{\mathrm{T}} \mathrm{Y}$, Obtained by the

least square method

$$
\mathcal{u}=\left(\mathbb{B}^{\mathbb{T}} \mathbb{B}\right)^{-1} \mathbb{B}^{\mathbb{T}} \mathbb{Y}_{\mathbb{1}}
$$

Among them :

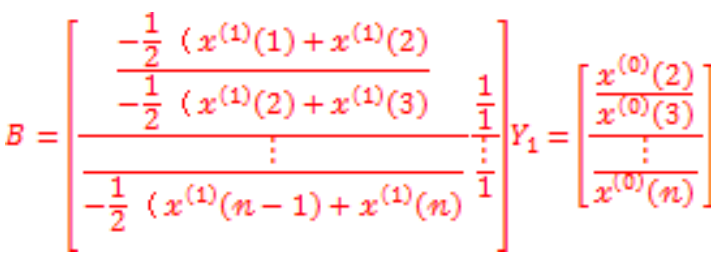

Then the solution of the differential equation is obtained. :

$$
x^{(1)}(k+1)=\left(x^{(0)}(1)-\frac{b}{a}\right) e^{-a t}+\frac{b}{a}
$$

According to the data of Fujian Jiangyin International Container Terminal Company in 2014-2017, the import volume series of foreign trade whole vehicles in Jiangyin Port are obtained: 
$X^{(0)}=(2294,3878,8311,10010)$

First step : Do a cumulative generation

$$
X^{(1)}=(2294,6112,14423,24433)
$$

The second step: Determine the data matrix B and

$$
B=\left[\begin{array}{l}
-3677 \\
-10729 \\
-21328.5
\end{array}\right], \quad Y_{1}=\left[\begin{array}{l}
3878 \\
8311 \\
10010
\end{array}\right]
$$

Third step: seek parameter a and b (Use Excel software to get the result)

$$
a=-0.3816, \quad b=3945.9746
$$

Therefore, the prediction model of the import volume of foreign trade whole vehicle is obtained as follows:

$$
\begin{aligned}
x^{(1)}(\kappa+1) & =\left(x^{(0)}(1)-\frac{b}{a}\right) e^{-a x}+\frac{b}{a} \\
& =11880.6043 \mathrm{e}^{03816 x}-10340.6043
\end{aligned}
$$

Among, $\mathrm{K}$ represents the number of interval years of the distance from the initial year, take $0,1,2, \ldots$

Test the prediction model:

According to the prediction model of the whole vehicle import in Jiangyin Port, the residuals between the import volume of foreign trade whole vehicles and the actual import volume of Jiangyin Port between 2012 and 2015 are calculated.

Take $a=-0.3816, b=3945.9746$ into the residual calculation formula

$$
x^{1}(k+1)=[11881.5212 * \exp (0.381566167 * t)-10341.5212]
$$

TABLE II. The RESIDUAL VALUE

\begin{tabular}{|l|l|}
\hline \multicolumn{1}{|c|}{ Year } & \multicolumn{1}{|c|}{ Residual Value } \\
\hline 2014 & 0 \\
\hline 2015 & 0.2915 \\
\hline 2016 & 0.1776 \\
\hline 2017 & 0.0414 \\
\hline
\end{tabular}

Comparison of residual values, conforming to the requirements of the construction model, therefore, this model is an accurate and effective model.

2) Import volume forecast: According to the residual test, this model can be used to predict effectively. This model is used to predict the import situation of whole vehicles Jiangyin port from 2018 to 2022, The $\mathrm{k}$ values in the existing model are brought in respectively $\kappa=4, \kappa=5, \kappa=6, \kappa=7$, $\kappa=8$, the EXCEL table is still used to calculate and solve the problem, thus, the predicted final value of the import volume of foreign trade whole vehicle in Jiangyin Port in 2018-2021 is obtained.
TABLE III. IMPORT VOLUME OF FOREIGN TRADE WHOLE VEHICLE IN JIANGYIN PORT IN 2018-2021

\begin{tabular}{|l|l|c|c|c|c|}
\hline \multicolumn{1}{|c|}{ Year } & $\mathbf{2 0 1 8}$ & $\mathbf{2 0 1 9}$ & $\mathbf{2 0 2 0}$ & $\mathbf{2 0 2 1}$ & $\mathbf{2 0 2 2}$ \\
\hline $\begin{array}{l}\text { Annual } \\
\text { import } \\
\text { volume }\end{array}$ & 12948 & 16246 & 18764 & 21027 & 24273 \\
\hline \multicolumn{5}{|c|}{ Data sources: Model EXCEL calculation results } \\
\hline
\end{tabular}

\section{Prediction and Analysis of the Import Volume of Foreign} Trade Whole Vehicle

According to the forecast results, the import volume of foreign trade whole vehicles in Jiangyin Port in 2018-2022is $12948,18246,25764,31027$ and 34273 respectively, the relative growth rate is about $46 \%$,in five years, the import volume of foreign trade whole vehicles will reach a record high of 34273 vehicles. According to the current basic situation of Jiangyin Port, it can be learned that at present the total land area in Jiangyin Port is about 49000 square meters, of which there are 1096 available parking spaces for customs supervision and storage yard, and there are 2 monitoring lines for inspection and collection, throughput of 100000 vehicles per year.[5]As can be seen from the forecast results, by 2022, the annual volume of foreign trade imported cars in Jiangyin Port has reached 34273 vehicles, together with import volume of domestic trade, it will break through the existing annual capacity of passage, and the storage capacity of the original storage yard and the capacity of inspection line passing are difficult to meet the needs of a large number of imported vehicles entering port. Compared with Shanghai, Dalian, and other large vehicle import ports, the annual passing capacity has reached millions of vehicles, they undertake the import of dozens of large automobile brands, Jiangyin port needs to make great efforts in many aspects such as hardware facilities, service level, information level and so on.

V. ANALYSIS ON THE IMPLEMENTATION STRATEGY OF THE IMPORT DEVELOPMENT OF THE WHOLE VEHICLE IN FUZHOU PORT

\section{A. Make Full Use of the Policy Advantage of the Free Trade Area}

Jiangyin Port, as the only port of import for whole vehicles on the west side of the Strait, has a good geographical advantage in trade with Taiwan. At the same time, in the context of the Free Trade Area, the government has repeatedly issued favorable policies for Taiwan, so as to give full play to the advantages of Fuzhou Port under the planning of "Belt and Road" .For example, it is necessary to promote the integration of automobile resources between Fujian and Taiwan, fully mobilize the resources of leading enterprises and superior enterprises in the automobile service industry of both sides of the Taiwan Strait, and implement a strong and strong joint effort. We should seize the good time for cooperation between Fujian and Taiwan, make full use of the connecting function of Taiwan airlines, and give full play to the high complementary role of the two sides. By strengthening the supporting services for imported vehicles, increasing investment in automobile imports, reintegrating related resources, jointly training professional talents, and using powerful policy lever to move Taiwan's automobile import resources gradually westward, 
Promoting the win-win cooperation between the two sides of the strait in automobile trade.

\section{B. Strengthening the Mating Construction of Infrastructure}

1) Construction of hardware facilities: Powerful hardware infrastructure reserve plays a key and fundamental role in the development of the port, and also plays a strong backing for Port development investment work. At present, we are facing the key problem that the port facilities will be difficult to meet the service needs of imported vehicles, the demand for the infrastructure in the port area includes increasing the number of imported vehicle inspection lines, increasing the parking area of the car yard and building the vehicle Rolling Wharf. At present, Jiangyin port is in the initial stage of the whole vehicle import business, the construction experience is not enough, and we can learn from the existing development experience of other ports, and strive to carry out the business while building, in order to promote the construction by promoting the business.

On the one hand, we are striving to join the most experienced and authoritative Rolling wharf branch Association of China Port Association. The application was jointly initiated by four units, Shanghai Haitong International Automobile Terminal Co., Ltd., Dalian automobile terminal Co., Ltd., Tianjin port rolling dock Co., Ltd., Guangzhou port Nansha automobile terminal Co., Ltd. The purpose of Rolling wharf branch Association of the China Port Association, which was established in May 2009, is to discuss and plan the development strategy of the rolling wharf from the actual production and management of the rolling wharf, and provide information and consulting services for the production and construction of the rolling wharf. The Rolling wharf branch Association will play a role as bridge tie and assistant role between the rolling dock enterprises and the government departments, reflecting the desire and demand of the port rolling enterprises and promoting the horizontal communication and cooperation between the rolling wharf. At present, Jiangyin Port is in the situation of zero-base experience in the development of rolling ships, it is necessary to learn a great deal of experience in excavating and carrying out rolling ship projects, therefore, it is suggested that Jiangyin Port should strive to join the association, in order to strengthen the communication and study with other whole vehicle ports and promote its own development, it is also to promote the development of China's whole vehicle ports together with other whole vehicle import ports.

On the other hand, the relevant port facilities should be built in moderate advance. According to the experience of the Shanghai whole vehicle import port, the construction of the port related facilities is an important driving factor to promote the development of the port business. Therefore, Jiangyin Port should strengthen the construction of port wharf and storage yard, automobile inspection line, customs supervision and other basic facilities as soon as possible. Among them, the wharf should be built in stages according to the situation of imported and exported vehicles in Qinzhou, and the automobile inspection lines may be built, Customs supervision facilities include setting up a isolated seine, setting up Channel entry and exit, and configuring Electronic railing and other clamping equipment, etc, Installing video surveillance system. On this basis, space is set aside to build warehouses, which can be used not only as temporary storage, but also as value-added services such as final quality inspection, component assembly, PDI (prefatory inspection) inspection and so on. Therefore, it is possible to further solve the problems such as the mismatch between the service capacity of facilities and the actual import volume, the amount of import exceeding the carrying capacity of the port, and so on, truly strengthen the service capacity of the port is the premise of the future port development.

2) Information equipment mating construction: By reading the whole vehicle import process specification of Jiangyin port, we know that the customs clearance process in Jiangyin port is still dominated by traditional customs clearance mode. To complete customs clearance, cargo owners are required to apply to the billing section and the operation section respectively for Clearing and unpacking operations, and to ensure that vehicles complete customs inspection and national inspection. The whole process is complicated, with many design departments, long completion time, low clearance efficiency, and the current customs clearance efficiency is very difficult to meet the needs of a large number of vehicles imported. Under the impetus of the current free trade zone policy, the government has stepped up the further adjustment of the free trade zone customs clearance model to speed up the customs clearance efficiency. While this policy is planned to be implemented, the paperless customs clearance mode can give full play to its facilitation advantages, compared with the traditional paper-based operation process, it can greatly improve the efficiency and shorten the operation time. However, in the actual operation of daily port operation, the conventional customs clearance process is difficult to realize the true information of the whole process, many of the operation links, such as inspection and quarantine, still require enterprises to provide paper materials, and, Many temporary shipping agencies or shipping companies have not been included in the existing electronic customs declaration platform, which easily leads to the flow link is not smooth, thus affecting the overall efficiency of the further improvement.

With the rapid development of high-tech and information Internet technology, computer network technology, data warehouse technology, graphic technology, GPS / GIS technology, wireless communication technology, information exchange technology, middleware technology, video digitalization and other high-tech media technology, have been deeply and extensively used in port management and production, In the daily operation of the port, through the use of technology as a help to integrate data, images, multimedia and other information data into a whole, carry out unified management and integration[6], so as to make the best use of the existing resource allocation of the wharf; through the application and management of advanced technology, sufficient information and data resources and information sharing platform are provided for the decision-making, management and management personnel in port operation, so 
as to further improve the experience and management level of port information management. But at the same time of informationization, we must pay attention to the technical standardization of all links in the whole vehicle import process. Ensure that in the process of informatization, minimize the error, so as to embody its information superiority.

\section{Promoting the Mating Development of Related Business}

1) Extend related industrial chain expansion: Extend the industrial chain of auto parts, maintenance, import of special vehicles, etc, and actively expand business related to whole vehicle import. Give full play to the advantages of the resources of Jiangyin Port Free Trade Area, to achieve the propelling development of attracting auto export trade of southeast coastal areas, to promote the transform from oneway flow of automobile logistics to two-way logistics, to reduce transportation costs. It is suggested that Jiangyin Port should carry out comprehensive planning with reference to the automobile integrated industrial chain, carry out comprehensive, scientific and reasonable planning of the port, and allocate two separate zones for the whole vehicle import business, one for the loading and unloading of automobiles, the other is used to carry out auto parts assembly, auto beauty and a series of related value-added business. So as to enhance the agglomeration effect and radiation effect of the port, in order to expand the comprehensive competitiveness of the port.

Under the condition of policy permitting, the multifunction refitting of Non-Central gauge car and Central gauge car in wharf can reduce the cost of refit to a great extent, and make the project of refit of vehicle in wharf carry out and develop smoothly. At the same time, we can improve and perfect the current environment of various facilities, speed up the construction of automobile logistics park, realize the refitting service for different brand vehicles, carry out the container whole vehicle import service to the parts logistics merchants and auto dealers, and extend various functions of the wharf to the maximum extent.

2) Building a powerful car collection, dispersion and transportation system: Jiangyin port has good geographical advantage and good geographical location, but it is always faced with the inconvenience of land transportation. So far, road traffic options to Jiangyin Port are still limited, and there is only one bus route to Jiangyin Port. In the face of such problems, the port area should speed up the construction of land transportation, excavate the auxiliary role of land traffic to the port development, and develop Jiangyin port automobile business to the maximum extent through the combination of water and land, through this advantage to reduce the cost of logistics, improve the efficiency of capital turnover. Further extend automobile logistics chain, innovate imported whole vehicle sea rail combined transport model.

3) Strengthening the construction of the "Internet +" and the Internet of things: At present, under the impetus of the "Internet + " era, the information platform and Internet operation mode have played a prominent role in many fields.
Similarly, as for imported car port, the effective use of "Internet + " resources, will also bring great opportunities for the development of the port. For example, port customs can use electronic label, or RFID technology, to monitor port data in real time. Under the basic condition of Internet of things and Internet of things, the wharf can build the wharf service platform based automobile RFID electronic label, take the automobile information service as the carrier, summarizes the vehicle logistics information (ship name, voyage number, bill of lading number, container number, Frame number, vehicle VIN identification code, engine number, brand, color, specification, motorcycle type, model, manufacturer, origin, output volume, etc.) big data, Establishes such as vehicle manifest declaration, vehicle parking space binding, exit inspection, inspection operation, manual release, vehicle departure from port, admission management, storage yard management, exit port management, logistics Management and etc Cloud Database of various links in automobile Information logistics operation process, combined with the "Internet + " promotion platform, All-directional customer service for regulators, cargo owners, shipping companies and so on, to enhance the soft power and profitability of the wharf. At the same time, a large number of operational data statistics will also provide strong data support for the unified standardized management of the port, and further maintain the good operation of the port.

\section{CONCLUSION}

In this paper, the Grey forecast method is used to forecast the import volume of foreign trade whole vehicles in Fuzhou Port in the next five years, and the conclusion is compared with the passing capacity of Fuzhou Port, under the background of the Free Trade area, the import volume of foreign trade whole vehicles in Fuzhou Port will increase greatly in the coming few years, but the current conditions in the port area cannot meet the needs of the import volume of a large number of foreign trade whole vehicles. In view of this problem, this paper takes the actual development of Jiangyin port in Fuzhou port as an example, proposes the corresponding suggestions from four aspects: making full use of the policy advantages of the free trade area, strengthening the construction of mating facilities, realizing the informationization of the operation process of the port area, and promoting the development of the related industries in the port area.

\section{ACKNOWLEDGMENT}

This paper is supported by the Outstanding Youth scientific research personnel training program of Fujian province.

\section{REFERENCES}

[1] Qiu Yuan,Zhang Benzhao.Analysis on the trend of Automobile consumption in China[J].Automotive industry research, 2006, (6): 8 13 邱媛,张本照.我国汽车消费趋势分析 [J].汽车工业研究, 2006, (6): $8-13$ 
[2] Saaty T L.TheAnalytle Hierarchy Process[M].New York:McGraw Hill.1980:1-29.

[3] Wang Chunli.Fujian's policy of opening to the outside world under the influence of Shanghai Free Trade Area[J].Academic Review,2014,(2):44-49 王春丽.上海自贸区影响下的福建对外开放政 策取向[J].学术评论,2014,(2):44-49

[4] Xu Xiaojian.Development and Countermeasures of port logistics under the background of Pilot Free Trade Area[J].Logistics engineering and management,2014, 36(3):107-116 徐小健.浅谈自贸试验区背景下港 口物流的发展与对策[J].物流工程与管理,2014, 36(3):107-116

[5] Bian Zhenhui.Application of Grey theory in forecasting product market demand[J].Chemical minerals and processing.2004,33(8):26 -27 边振辉. 灰色理论在产品市场需求预测中的应用 [J]. 化工矿物与加 工.2004,33(8):26 -27

[6] BojanBeskovnik,ElenTwrdy. Managing maritime automobile terminals: an approach toward 